\title{
DETERMINAN PERILAKU REMAJA MEROKOK SETIAP HARI DI INDONESIA
}

\author{
(Determinant of Adolescent Behavior for Smoking Every Day in Indonesia) \\ Charvia Ismi Zahrani ${ }^{1}$, I Made Arcana ${ }^{2}$ \\ Politeknik Statistika STIS ${ }^{1,2}$ \\ Jalan Otista No.64C RT.1/RW.4, Bidara Cina, Jatinegara, Jakarta Timur. \\ E-mail: 16.9051@stis.ac.id
}

\begin{abstract}
ABSTRAK
Prevalensi remaja yang merokok terus mengalami kenaikan pada beberapa tahun terakhir. Lebih dari separuh remaja yang merokok merupakan perokok setiap hari. Kebiasaan merokok yang dimulai sejak remaja akan meningkatkan ketergantungan pada masa tua. Hal ini sangat mengkhawatirkan mengingat dampak negatif dari merokok dapat menyebabkan berbagai macam penyakit hingga kematian. Risiko ini akan meningkat apabila perilaku merokok dilakukan setiap hari. Penelitian ini bertujuan untuk mengetahui karakteristik sosial demografi yang memengaruhi perilaku remaja merokok setiap hari di Indonesia beserta kecenderungannya. Analisis deskriptif dan analisis regresi logistik biner dilakukan pada data remaja berusia 15-24 tahun yang merokok yang bersumber dari data Riskesdas 2018. Hasil penelitian menunjukkan bahwa jenis kelamin, status wilayah tempat tinggal, status perkawinan, tingkat pendidikan, status bekerja, dan usia pertama merokok memiliki pengaruh signifikan terhadap perilaku merokok setiap hari. Kecenderungan terbesar untuk berperilaku merokok setiap hari ditunjukkan oleh remaja laki-laki, remaja berstatus bekerja, dan remaja yang merokok pertama kali pada usia di bawah 18 tahun.
\end{abstract}

Kata kunci: rokok, merokok setiap hari, remaja, regresi logistik biner

\section{ABSTRACT}

Prevalence of adolescents being smoke has continued to increase in recent years. More than half of adolescents being smoke are daily smokers. Smoking habits being started in adolescence will increase dependence in smoking on old age. This condition is quite concerning considering the negative effects of smoking can cause various diseases and even death. This risk will increase if smoking behavior is performed every day. This research aims to determine the socio-demographic characteristics affecting the behavior of adolescents being smoke every day in Indonesia and their tendencies. Descriptive analysis and binary logistic regression analysis were carried out on data from adolescents aged 15-24 years who smoke sourced from Riskesdas 2018 data. The results showed that gender, residence status, marital status, education level, work status, and age at first smoking has a significant effect on smoking behavior every day. The greatest tendency to smoke behavior every day was shown by male adolescents, adolescents with working status, and adolescents who first smoked at the age of under 18 years.

Keywords: smoke, daily smoking behavior, adolescent, binary logistic regression

\section{PENDAHULUAN}

Masalah merokok merupakan salah satu fokus yang dimuat dalam tujuan ke-3 SDGs yaitu mengurangi sepertiga kematian dini yang disebabkan oleh penyakit tidak menular, salah satunya dengan melakukan pengendalian terhadap konsumsi tembakau di setiap negara. Indonesia menghadapi ancaman serius akibat banyaknya jumlah perokok. Lebih dari separuh perokok usia 15 tahun ke atas di negara-negara ASEAN pada Tahun 2016 merupakan penduduk Indonesia. Jumlah ini setara dengan 28,97 persen penduduk usia 15 tahun ke atas di Indonesia yang pada Tahun 2017 mengalami peningkatan menjadi 29,25 persen.

World Health Organization (2017) mengemukakan bahwa lebih dari 7 juta kematian per tahun disebabkan oleh rokok dan angka ini diperkirakan akan meningkat menjadi lebih dari 10 juta kematian per tahun pada tahun 2030. Badan Penelitian dan Pengembangan Kesehatan (Litbangkes) menunjukkan bahwa Indonesia menyumbang lebih dari 230 ribu kematian akibat konsumsi tembakau setiap tahunnya (Kemkes, 2019). Senyawa adiktif yang terkandung di dalam 
rokok membuat rokok menjadi kebutuhan sehari-hari bagi sebagian orang, padahal risiko terkena penyakit akibat merokok menjadi lebih tinggi pada mereka yang merokok setiap hari. Seseorang yang menghisap satu batang rokok setiap hari memiliki resiko sekitar 50 persen lebih tinggi untuk terkena penyakit jantung koroner dan sekitar 25 persen lebih tinggi untuk terkena stroke (Hackshaw, 2018).

Hasil Riskesdas Tahun 2018 menunjukkan bahwa proporsi penduduk berusia 10 tahun ke atas yang merokok adalah 28,9 persen, dimana 84,1 persen diantaranya merupakan perokok setiap hari. Pemerintah telah menerbitkan regulasi tentang pengamanan rokok bagi kesehatan berupa PP No. 109 Tahun 2012 sebagai salah satu upaya preventif untuk menurunkan jumlah perokok di Indonesia, termasuk perokok di kalangan remaja.

Kategori remaja menurut PBB adalah penduduk dengan usia 15-24 tahun. Masa remaja adalah masa peralihan dimana banyak masalah dan tekanan serta pencarian jati diri. Menurut Yusuf (2004) masa remaja juga dikenal dengan masa storm and stress dimana terjadi pergolakan emosi yang diiringi pertumbuhan fisik yang pesat dan pertumbuhan psikis yang bervariasi. Oleh karena itu, rokok menjadi salah satu pelarian bagi para remaja. Kondisi remaja merokok di Indonesia saat ini sangat memprihatinkan karena jumlah perokok setiap hari di kalangan remaja jauh lebih banyak seperti terlihat pada Gambar 1. Pada Tahun 2018, sebanyak 53,81 persen remaja usia 15-19 dan sebanyak 74,39 persen remaja usia 20-24 tahun yang merokok merupakan perokok setiap hari.

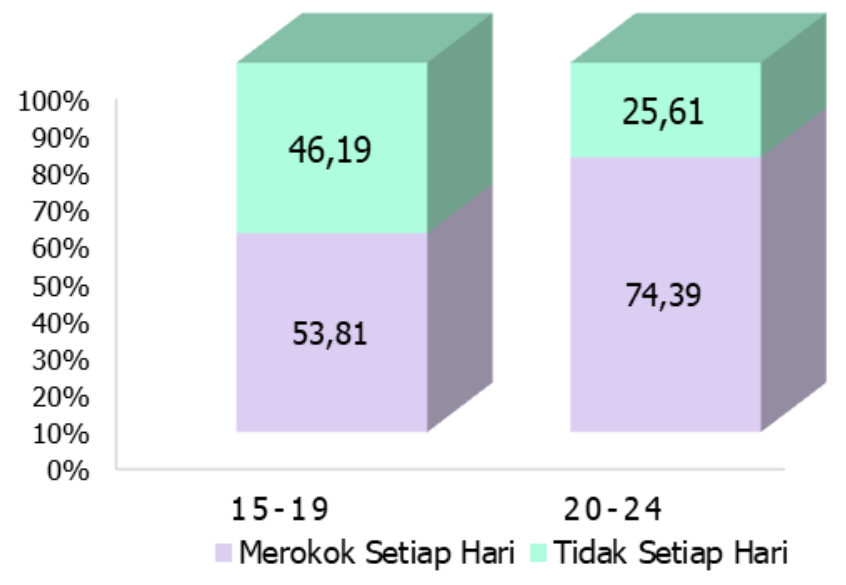

Sumber: Riskesdas 2018

Gambar 1. Persentase remaja merokok di Indonesia menurut kelompok umur dan frekuensi merokoknya.

Perilaku merokok setiap hari yang dimulai sejak remaja menjadi sebuah ancaman bagi kesehatan. Hal ini dihubungkan dengan besarnya kemungkinan remaja mengalami adiksi pada sisa hidupnya yang otomatis meningkatkan risiko terkena penyakit akibat merokok (Sutha, 2018). Kebiasaan merokok setiap hari sejak remaja merupakan masalah penting, mengingat perilaku hidup sehat sejak usia dini merupakan salah satu upaya menciptakan sumber daya manusia yang produktif dan berkualitas di masa mendatang (WHO, 2015).

Kebiasaan merokok tidak hanya dipengaruhi oleh faktor individu tetapi juga dipengaruhi oleh beberapa faktor lainnya termasuk faktor sosial dan demografi. Beberapa penelitian menyatakan bahwa faktor sosial demografi memengaruhi seseorang untuk merokok setiap hari. Penelitian di Amerika Serikat yang dilakukan oleh Guzman, et al (2016) menunjukkan bahwa perokok setiap hari memiliki karakteristik berjenis kelamin laki-laki, berstatus kawin, tingkat pendidikan menengah, dan mulai merokok sejak usia kurang dari 18 tahun. Penelitian lain di New Zealand menemukan fakta bahwa remaja yang merokok setiap hari cenderung berjenis kelamin laki-laki, etnis Maori, berstatus migran, dan memiliki pekerjaan (Stanton, Oei, \& Silva, 1994).

Penelitian mengenai faktor yang memengaruhi remaja untuk merokok sudah pernah dilakukan di Indonesia, namun tidak secara rinci memisahkan perilaku merokok setiap hari atau tidak. Oleh karena itu, penelitian ini bertujuan untuk mengetahui gambaran umum remaja yang merokok 
setiap hari di Indonesia, serta mengidentifikasi karakteristik sosial demografi yang memengaruhinya.

\section{METODE}

\section{Kajian Teori}

Dewasa ini merokok disebut sebagai tobacco dependency atau ketergantungan pada tembakau yang dipersepsikan sebagai kenikmatan yang memberikan kepuasan psikologis. Perilaku merokok merupakan sesuatu yang menyenangkan dan bergeser menjadi aktivitas yang bersifat obsesif dan dilakukan setiap hari oleh sebagian orang (Komasari, 2000). Merokok sejak remaja menjadi perhatian khusus karena telah banyak penelitian mengungkapkan bahwa merokok pada usia remaja memiliki kecenderungan yang relatif kuat untuk menjadi perokok setiap hari di usia dewasa. Semakin muda usia seseorang ketika mulai merokok, akan meningkatkan jumlah rokok yang dikonsumsi pada usia tuanya (Colby, et al., 2000).

World Health Organization (WHO) mengemukakan bahwa terdapat perbedaan yang besar pada prevalensi merokok antara laki-laki dan perempuan. Perilaku merokok pada laki-laki adalah perilaku yang dianggap normal oleh masyarakat Indonesia dan bahkan dianggap sebagai simbol kejantanan (Martini, 2014). American Lung Association (2015) menyatakan bahwa penduduk di wilayah perdesaan memiliki tingkat merokok yang lebih tinggi dibanding penduduk di wilayah perkotaan. Kondisi ini sejalan dengan penelitian Lutfiyya (2008) yang memperlihatkan bahwa daerah tempat tinggal merupakan faktor yang signifikan memengaruhi perilaku merokok. Remaja yang tinggal di daerah perdesaan memiliki kecenderungan lebih tinggi untuk merokok setiap hari dibanding remaja yang tinggal di daerah perkotaan.

Wang \& Sung (2017) melibatkan variabel status perkawinan dalam penelitiannya terkait perilaku merokok setiap hari dan menyatakan bahwa seseorang yang berstatus kawin cenderung untuk merokok setiap hari dibandingkan mereka yang belum kawin atau telah bercerai. Shiffman, et al (2012) mengemukakan bahwa seseorang yang merokok setiap hari cenderung tinggal bersama pasangannya yang juga perokok. Lenk (2009) menyampaikan bahwa remaja dengan tingkat pendidikan tamat SMP ke bawah memiliki kecenderungan lebih tinggi untuk merokok setiap hari dibandingkan remaja berpendidikan tamat SMA ke atas.

Pada Tahun 2013, rata-rata konsumsi rokok per hari lebih tinggi pada individu dengan status bekerja dibanding tidak bekerja (Kemkes, 2018). Diungkapkan oleh Stanton, Oei, \& Silva (1994) dalam penelitiannya, remaja yang bekerja cenderung untuk merokok setiap hari daripada remaja yang tidak bekerja. Lenk (2009) menunjukkan bahwa mereka yang mulai merokok pada usia yang lebih muda memiliki kecenderungan menjadi perokok setiap hari dibandingkan mereka yang mulai merokok pada usia lebih tua. Penelitian Rubinstein (2014) menyatakan bahwa semakin muda usia seseorang pertama kali merokok akan meningkatkan peluang untuk menjadi perokok setiap hari karena semakin lama durasi seseorang menjadi perokok akan meningkatkan ketergantungan mereka terhadap nikotin.

\section{Sumber Data}

Data yang digunakan merupakan data sekunder cross-sectional yang berasal dari Riset Kesehatan Dasar (Riskesdas) tahun 2018 yang diselenggarakan oleh Badan Penelitian dan Pengembangan Kesehatan (Balitbangkes) Kementrian Kesehatan Republik Indonesia, yang bekerjasama dengan Badan Pusat Statistik (BPS). Unit analisis dalam penelitian ini adalah remaja usia 15-24 tahun yang merokok yaitu sebanyak 39.508 penduduk. Variabel-variabel yang digunakan dalam penelitian ini dapat dilihat pada Tabel 1.

\section{Metode Analisis}

Metode analisis yang diterapkan dalam penelitian ini dibagi menjadi analisis deskriptif dan analisis inferensia. Analisis deskriptif ditujukan untuk melihat gambaran umum perilaku remaja merokok setiap hari di Indonesia. Sedangkan analisis inferensia menerapkan regresi logistik biner untuk melihat pengaruh jenis kelamin, status wilayah tempat tinggal, status perkawinan, tingkat 
pendidikan, status bekerja, dan usia pertama merokok terhadap perilaku remaja merokok setiap hari di Indonesia.

Tabel 1. Ringkasan kategori variabel

\begin{tabular}{ll}
\hline \multicolumn{1}{c}{ Variabel } & \multicolumn{1}{c}{ Kategori } \\
\hline Status perilaku merokok setiap hari $(\mathrm{G})$ & $1=$ setiap hari, $0=$ tidak setiap hari \\
\hline Jenis kelamin (JK) & $1=$ Laki-laki, $0=$ perempuan \\
\hline Status wilayah tempat tinggal (Wil) & $1=$ perdesaan, $0=$ perkotaan \\
\hline Status perkawinan (Kawin) & $1=$ kawin, $0=$ tidak kawin \\
\hline Tingkat Pendidikan (Pend) & $1=\leq$ SMP $/$ sederajat, $0=\geq$ SMA/sederajat \\
\hline Status bekerja (Statker) & $1=$ bekerja, $0=$ tidak bekerja \\
\hline Usia pertama merokok (UPM) & $1=<18$ tahun, $0=\geq 18$ tahun
\end{tabular}

Regresi Logistik Biner

Regresi logistik biner merupakan metode yang digunakan untuk menggambarkan hubungan antara variabel respons (dependent variable) dengan satu atau lebih variabel penjelas (independent variables), dimana variabel responsnya bersifat dikotomi. Kejadian sukses dinotasikan dengan $Y=1$, sedangkan kejadian gagal dinotasikan dengan $Y=0$.

Tahapan yang dilakukan dalam regresi logistik biner adalah sebagai berikut:

1. Uji Independensi

Uji Independensi diterapkan dengan tujuan untuk memeriksa hubungan dua kelompok yang bersifat kategorik dan saling independen. Pengujian dilakukan menggunakan hipotesis sebagai berikut:

$\mathrm{H}_{0}$ : Tidak ada hubungan antara variabel penjelas dan perilaku merokok setiap hari

$\mathrm{H}_{1}$ : Terdapat hubungan antara variabel penjelas dan perilaku merokok setiap hari

Pengujian hipotesis dilakukan menggunakan statistik uji Chi Square $\left(\chi^{2}\right)$ sebagai berikut:

$$
\chi^{2}{ }_{o b s}=\sum_{i=1}^{r} \sum_{j=1}^{k} \frac{\left(o_{i j}-E_{i j}\right)^{2}}{E_{i j}} \sim \chi_{(r-1)(k-1)}^{2}
$$

dimana:

$\mathrm{O}_{\mathrm{ij}}$ : frekuensi observasi pada kategori baris ke-i kolom ke-j

$\mathrm{E}_{\mathrm{ij}}$ : frekuensi harapan pada baris ke-i kolom ke-j

$r$ : jumlah kategori pada baris

k : jumlah kategori pada kolom

Keputusan untuk menolah $\mathrm{H}_{0}$ pada tingkat signifikansi $(\alpha)$ sebesar 5 persen diterapkan apabila nilai $\chi_{\text {obs }}^{2}>\chi_{0,05 ;(r-1)(k-1)}^{2}$ atau $p$-value $\leq 0,05$. Ketika $\mathrm{H}_{0}$ ditolak, artinya terdapat hubungan antara variabel penjelas dan perilaku remaja merokok setiap hari. Setelah diketahui variabel penjelas yang memiliki hubungan dengan perilaku merokok setiap hari, maka dapat dibentuk kandidat model dari kombinasi seluruh variabel yang digunakan dalam model.

2. Pembentukan model

Model regresi logistik biner yang akan terbentuk adalah sebagai berikut

$$
g(x)=\beta_{0}+\beta_{1} x_{1}+\cdots+\beta_{6} x_{6}
$$

dimana: 
$g(x)=\operatorname{logit} \pi(x)$

$\beta_{0}=$ parameter intercept

$\beta_{1} \ldots \beta_{6}=$ nilai parameter atau koefisien regresi

$x_{1} \ldots x_{6}=$ nilai variabel independen dalam model

\section{Pemilihan kandidat model terbaik}

Dari seluruh kandidat model yang dibentuk, kemudian dilakukan pemilihan model terbaik menggunakan Akaike Information Criterion (AIC). Model yang dipilih merupakan model yang memiliki nilai AIC terkecil serta nilai correctly classified terbesar tanpa mengesampingkan principle of parsimony, yaitu mengutamakan kesederhanaan model.

\section{Uji Simultan}

Uji simultan digunakan untuk menguji pengaruh variabel penjelas secara bersama-sama terhadap perilaku remaja merokok setiap hari. Pengujian ini menggunakan hipotesis sebagai berikut:

$\mathrm{H}_{0}$ : Tidak ada pengaruh signifikan dari variabel penjelas secara simultan terhadap perilaku merokok setiap hari

$\mathrm{H}_{1}$ : Minimal terdapat satu variabel penjelas yang signifikan berpengaruh terhadap perilaku merokok setiap hari

Statistik uji yang digunakan adalah statistik uji Likelihood Ratio (G) sebagai berikut:

$$
G=-2 \ln \left(\frac{L_{0}}{L_{1}}\right)=-2\left[\ln \left(L_{0}\right)-\ln \left(L_{1}\right)\right]
$$

dimana:

$\mathrm{L}_{0}$ : nilai likelihood tanpa variabel penjelas

$\mathrm{L}_{1}$ : nilai likelihood dengan $\mathrm{p}$ variabel penjelas.

Keputusan tolak $\mathrm{H}_{0}$ dilakukan pada tingkat signifikansi $(\alpha)$ sebesar 5 persen apabila $G>\chi_{(0,05 ; p)}^{2}$ atau $p$-value $\leq 0,05$. Saat $\mathrm{H}_{0}$ ditolak, dapat ditarik kesimpulan bahwa minimal terdapat satu variabel penjelas yang berpengaruh signifikan terhadap perilaku remaja merokok setiap hari.

\section{Uji Parsial}

Uji parsial adalah pengujian yang diterapkan pada parameter model untuk mendeteksi variabel penjelas yang berpengaruh secara signifikan terhadap variabel respons. Hipotesis yang digunakan dalam pengujian ini adalah sebagai berikut:

$\mathrm{H}_{0}$ : Tidak ada pengaruh signifikan dari variabel penjelas terhadap perilaku merokok setiap hari

$\mathrm{H}_{1}$ : Terdapat pengaruh signifikan dari variabel penjelas terhadap perilaku merokok setiap hari

Statistik uji yang digunakan adalah statistik uji Wald (W) sebagai berikut:

$$
W=\left(\frac{\widehat{\beta}_{i}}{\operatorname{se}\left(\widehat{\beta}_{i}\right)}\right)^{2}
$$

dimana:

$\hat{\beta}_{i} \quad$ : penduga parameter ke-i, dimana $\mathrm{i}=1,2, \ldots, \mathrm{p}$

se $\left(\hat{\beta}_{i}\right)$ : standar error dari penduga parameter ke-i 
Keputusan tolak $\mathrm{H}_{0}$ pada tingkat signifikansi $(\alpha) 5$ persen dilakukan apabila $\mathrm{W}>\chi_{(0,05 ; 1)}^{2}$ atau $p$-value $\leq 0,05$. Saat $\mathrm{H}_{0}$ ditolak, dapat ditarik kesimpulan bahwa variabel penjelas berpengaruh signifikan terhadap perilaku remaja merokok setiap hari.

\section{Odds ratio}

Interpretasi parameter dilakukan menggunakan nilai odds ratio yang merupakan rasio antar odds individu yang mengalami peristiwa tertentu dengan odds individu yang tidak mengalami peristiwa tersebut sebagai kelompok referensi. Nilai odds ratio diterapkan untuk memperkirakan besar kecenderungan suatu variabel penjelas terhadap variabel respons untuk mengalami suatu kejadian, yang dihitung berdasarkan nilai dari $\exp (\beta)$.

\section{HASIL DAN PEMBAHASAN}

\section{Analisis Deskriptif}

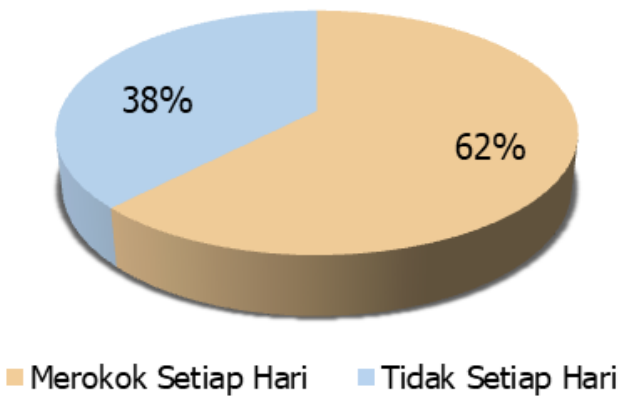

Sumber: Riset Kesahatan Dasar 2018 (diolah)

Gambar 2. Persentase remaja merokok menurut status merokok Tahun 2018

Berdasarkan Gambar 2 diketahui bahwa mayoritas (62 persen) remaja yang merokok merupakan perokok setiap hari, sementara 38 persen remaja yang merokok tidak setiap hari.

Tabel 2. Persentase remaja merokok setiap hari berdasarkan kategori variabel

\begin{tabular}{|c|c|c|c|}
\hline Variabel & Kategori & Persentase & Total \\
\hline (1) & $(2)$ & (3) & $(4)$ \\
\hline \multirow{2}{*}{ Jenis kelamin } & Laki-laki & 98,74 & \multirow[t]{2}{*}{100} \\
\hline & Perempuan & 1,26 & \\
\hline \multirow{2}{*}{$\begin{array}{l}\text { Status wilayah tempat } \\
\text { tinggal }\end{array}$} & Perdesaan & 55,86 & \multirow[t]{2}{*}{100} \\
\hline & Perkotaan & 44,14 & \\
\hline \multirow{2}{*}{ Status perkawinan } & Kawin & 21,86 & \multirow[t]{2}{*}{100} \\
\hline & Tidak Kawin & 78,14 & \\
\hline \multirow{2}{*}{ Tingkat Pendidikan } & $\leq \mathrm{SMP} /$ sederajat & 55,32 & \multirow[t]{2}{*}{100} \\
\hline & $\geq$ SMA/sederajat & 44,68 & \\
\hline \multirow{2}{*}{ Status bekerja } & Bekerja & 40,97 & \multirow[t]{2}{*}{100} \\
\hline & Tidak bekerja & 59,03 & \\
\hline \multirow{2}{*}{ Usia pertama merokok } & $<18$ tahun & 83,13 & \multirow[t]{2}{*}{100} \\
\hline & $\geq 18$ tahun & 16,87 & \\
\hline
\end{tabular}

Berdasarkan Tabel $\mathbf{2}$ terlihat bahwa variabel yang memiliki selisih persentase di atas 50 persen poin adalah variabel jenis kelamin, status perkawinan, dan usia pertama merokok. Sedangkan variabel lainnya memiliki persentase yang relatif sama antarkategori. Hampir seluruh remaja yang merokok setiap hari (98,74 persen) berjenis kelamin laki-laki. Remaja yang merokok setiap hari dengan status tidak kawin sebesar 78,14 persen dan yang pertama kali merokok pada 524 
usia di bawah 18 tahun sebesar 83,13 persen. Lebih dari separuh remaja yang merokok setiap hari tinggal di daerah perdesaan, berpendidikan maksimal tamatan SMP/sederajat, dan berstatus tidak bekerja.

\section{Analisis Inferensia}

Uji Independensi

Hasil uji independensi yang telah dilakukan ditunjukkan pada Tabel 3. Terlihat bahwa semua nilai $p$-value yang diperoleh pada masing-masing variabel penjelas kurang dari 0,05 , sehingga keputusan yang diambil adalah Tolak $\mathrm{H}_{0}$. Dengan demikian, disimpulkan bahwa masing-masing variabel penjelas memiliki hubungan yang signifikan dengan perilaku remaja merokok setiap hari.

Tabel 3. Hasil Uji Independensi

\begin{tabular}{lrc}
\hline \multicolumn{1}{c}{ Variabel Penjelas } & \multicolumn{1}{c}{$\boldsymbol{\chi}^{\mathbf{2}}$} & \multicolumn{1}{c}{$\boldsymbol{p}$-value } \\
\hline Jenis Kelamin & \multicolumn{1}{c}{$(2)$} & \multicolumn{1}{c}{$(3)$} \\
\hline Status Wilayah Tempat Tinggal & 735,25 & 0,000 \\
\hline Status Perkawinan & 30,35 & 0,000 \\
\hline Tingkat Pendidikan & 294,79 & 0,000 \\
\hline Status Bekerja & 114,27 & 0,000 \\
\hline Usia Pertama Merokok & 2253,15 & 0,000 \\
\hline
\end{tabular}

Pembentukan Model dan Pemilihan Kandidat Model Terbaik

Setelah diketahui semua variabel penjelas memiliki hubungan yang signifikan terhadap variabel respons, maka keenam variabel penjelas dapat digunakan untuk membentuk kandidat model. Terdapat 64 kandidat model yang memuat kombinasi dari variabel penjelas, kemudian dilakukan perhitungan nilai AIC serta persentase correctly classified. Hasil menunjukkan bahwa kandidat model terbaik yang dapat digunakan untuk menjelaskan pengaruh perilaku remaja merokok setiap hari adalah model yang memuat keseluruh variabel penjelas, yaitu jenis kelamin, status wilayah tempat tinggal, status perkawinan, tingkat pendidikan, status bekerja, dan usia saat pertama kali merokok. Model ini memiliki nilai AIC terkecil serta nilai correctly classified terbesar yaitu 65,06 persen. Hal ini menggambarkan bahwa keakuratan model secara keseluruhan dalam mengidentifikasi kejadian "sukses" sebagai "sukses" dan mengidentifikasi kejadian "gagal" sebagai "gagal" adalah sebesar 65,06 persen. Model yang dipilih memiliki persamaan sebagai berikut:

$$
\widehat{\boldsymbol{g}(\boldsymbol{x})}=\hat{\beta}_{0}+\hat{\beta}_{1} \mathrm{JK}+\hat{\beta}_{2} \text { Wil }+\hat{\beta}_{3} \text { Kawin }+\hat{\beta}_{4} \text { Pend }+\hat{\beta}_{5} \text { Statker }+\hat{\beta}_{6} \mathrm{UPM}
$$

\section{Uji Simultan}

Menggunakan uji rasio likelihood nilai $\mathrm{G}$ yang diperoleh adalah 4370,75 atau $p$-value 0,000 . Hipotesis nol ditolak karena nilai G lebih besar dari $\chi_{(0,05 ; 6)}^{2}=12,59$ atau $p$-value kurang dari 0,05.

Hal ini menunjukkan pada tingkat signifikansi 5 persen, dapat disimpulkan bahwa minimal terdapat satu dari enam variabel penjelas yang berpengaruh terhadap perilaku remaja merokok setiap hari di Indonesia.

\section{Uji Parsial}

Setelah dilakukan pengujian parameter secara simultan dan hasilnya tolak $\mathrm{H}_{0}$, maka tahapan selanjutnya adalah melakukan pengujian parameter secara parsial. Pada Tabel $\mathbf{4}$ terlihat bahwa seluruh variabel penjelas mempunyai nilai statistik uji $W$ yang lebih besar dari $\chi_{(0,05 ; 1)}^{2}=3,841$ 
kelamin, status wilayah tempat tinggal, status perkawinan, tingkat pendidikan, status bekerja, dan usia saat pertama kali merokok berpengaruh secara parsial terhadap perilaku remaja merokok setiap hari di Indonesia. Dengan demikian, model yang digunakan merupakan model terbaik dan sudah sesuai untuk diterapkan pada data yang tersedia.

\begin{tabular}{lccr}
\hline \multicolumn{1}{c}{ Variabel } & $\widehat{\boldsymbol{\beta}}$ & $\mathbf{W}$ & $\boldsymbol{p}$-value \\
\hline \multicolumn{1}{c}{$(1)$} & $(2)$ & $(3)$ & $(4)$ \\
\hline Jenis Kelamin & 1,5711 & 500,430 & 0,000 \\
\hline Status Wilayah Tempat Tinggal & 0,092 & 16,694 & 0,000 \\
\hline Status Perkawinan & 0,351 & 89,761 & 0,000 \\
\hline Tingkat Pendidikan & 0,276 & 141,397 & 0,000 \\
\hline Status Pekerjaan & 1,066 & 1993,601 & 0,000 \\
\hline Usia Pertama Merokok & 1,013 & 1356,937 & 0,000 \\
\hline Constant & $-2,509$ & 1087,465 & 0,000 \\
\hline
\end{tabular}

Berdasarkan Tabel 4 dapat dibuat model persamaan regresi logistik biner yang menjelaskan variabel-variabel yang memengaruhi perilaku remaja merokok setiap hari remaja di Indonesia. Secara matematis persamaan modelnya dapat dituliskan sebagai berikut :

$$
\begin{gathered}
\overrightarrow{g(x)}=-2,509+1,571 \text { JK }+0,092 \text { Wil }+0,351 \text { Kawin }+0,276 \text { Pend } \\
+1,066 \text { Statker }+1,013 \text { UPM }
\end{gathered}
$$

Keterangan :

$\mathrm{JK} \quad=$ Jenis kelamin

Wil = Status wilayah tempat tinggal

Kawin = Status perkawinan

Pend = Tingkat pendidikan

Statker = Status bekerja

UPM = Usia saat pertama kali merokok

\section{Odds Ratio}

Tingkat kecenderungan dari kategori tertentu terhadap kategori referensi dalam suatu variabel penjelas terhadap variabel respons dilihat dari nilai odds ratio yang diperoleh dari hasil exponensial koefisien $\beta$. Kecenderungan dari masing-masing variabel yang memengaruhi perilaku remaja untuk merokok setiap hari dapat dilihat pada Tabel 5.

\begin{tabular}{|c|c|c|c|}
\hline Variabel & Kategori & $\widehat{\boldsymbol{\beta}}$ & $\operatorname{Exp}(\widehat{\beta})$ \\
\hline$(1)$ & $(2)$ & (3) & $(4)$ \\
\hline \multirow[t]{2}{*}{ Jenis Kelamin } & Laki-laki & \multirow[t]{2}{*}{1,5711} & \multirow[t]{2}{*}{4,811} \\
\hline & Perempuan* & & \\
\hline \multirow[t]{2}{*}{ Status Wilayah } & Perdesaan & \multirow[t]{2}{*}{0,092} & \multirow[t]{2}{*}{1,096} \\
\hline & Perkotaan* & & \\
\hline \multirow[t]{2}{*}{ Status Perkawinan } & Pernah Kawin & \multirow[t]{2}{*}{0,351} & \multirow[t]{2}{*}{1,421} \\
\hline & Belum Kawin* & & \\
\hline \multirow[t]{2}{*}{ Tingkat Pendidikan } & SMP/Sederajat kebawah & \multirow[t]{2}{*}{0,276} & \multirow[t]{2}{*}{1,318} \\
\hline & SMA/Sederajat keatas* & & \\
\hline \multirow[t]{2}{*}{ Status Pekerjaan } & Bekerja & \multirow[t]{2}{*}{1,066} & \multirow[t]{2}{*}{2,903} \\
\hline & Tidak Bekerja* & & \\
\hline Usia Pertama Merokok & $<18$ Tahun & 1,013 & 2,754 \\
\hline
\end{tabular}

Tabel 5. Nilai odds ratio variabel penjelas 
$\geq 18$ Tahun*

Keterangan: * adalah kategori referensi

Berdasarkan nilai odds ratio pada Tabel 4 diketahui bahwa :

1. Remaja laki-laki memiliki kecenderungan 4,811 kali untuk merokok setiap hari dibandingkan remaja perempuan.

2. Kecenderungan remaja yang tinggal di wilayah perdesaan 1,096 kali untuk merokok setiap hari dibandingkan remaja yang tinggal di wilayah perkotaan.

3. Remaja dengan status kawin memiliki kecenderungan 1,421 kali untuk merokok setiap hari dibanding remaja dengan status tidak kawin.

4. Remaja dengan tingkat pendidikan SMP/sederajat ke bawah memiliki kecenderungan 1,318 kali untuk merokok setiap hari dibanding remaja dengan tingkat pendidikan SMA/sederajat ke atas.

5. Kecenderungan dari remaja yang bekerja untuk merokok setiap hari adalah 2,903 kali dibandingkan remaja yang tidak bekerja.

6. Remaja yang pertama kali merokok pada usia di bawah 18 tahun memiliki kecenderungan 2,754 kali untuk merokok setiap hari dibandingkan remaja yang pertama kali merokok saat berusia 18 tahun ke atas.

\section{KESIMPULAN}

Lebih dari 60 persen remaja di Indonesia yang merokok merupakan perokok setiap hari dan lebih dari 75 persen diantaranya adalah remaja laki-laki, berstatus tidak kawin, dan mulai merokok sebelum berusia 18 tahun. Disamping itu, lebih dari separuh remaja yang merokok setiap hari merupakan remaja yang tinggal di perdesaan, tamatan SMP ke bawah, dan berstatus tidak bekerja.

Karakteristik sosial demografi yang signifikan memengaruhi perilaku remaja merokok setiap hari di Indonesia adalah jenis kelamin, status wilayah tempat tinggal, status perkawinan, tingkat pendidikan, status bekerja, dan usia pertama merokok. Kecenderungan tertinggi adalah jenis kelamin, dimana remaja laki-laki berpeluang hampir 5 kali lebih besar untuk merokok setiap hari dibandingkan perempuan. Sementara kecenderungan terkecil adalah status wilayah tempat tinggal, dimana remaja yang tinggal di perdesaan dan perkotaan memiliki kecenderungan yang hampir sama untuk merokok setiap hari.

Guna mengurangi perilaku kebiasaan remaja merokok, maka diperlukan perhatian lebih terhadap kondisi merokok di kalangan remaja, salah satunya dengan memberikan edukasi mengenai bahaya merokok sejak usia dini baik melalui seminar yang diadakan di sekolah maupun melalui media sosial. Kecenderungan tertinggi remaja merokok setiap hari adalah pada laki-laki. Oleh karena itu, perlu adanya pembatasan iklan-iklan rokok yang dapat memunculkan presepsi bahwa merokok adalah simbol kejantanan atau maskulinitas. Selain itu, pemerintah sebaiknya membuat kebijakan yang tegas berupa pemberlakuan sanksi bagi perokok yang merokok pada Kawasan Tanpa Rokok serta menaikkan cukai rokok sehingga rokok tidak mudah dijangkau oleh semua kalangan, terutama kalangan anak-anak dan remaja.

\section{DAFTAR PUSTAKA}

American Lung Association. (2015). Cutting Tobacco's Rural Roots: Tobacco Use in Rural Communities diakses pada 20 Mei 2020 melalui https://www.lung.org/getmedia/429eb03a-9196-47bb-9912e47e835d4466/cutting-tobaccos-rural-roots.pdf

Colby, M. S., Tiffany, T. S., Shiffman, S., \& Niaura, S. R. (2000). Are Adolescent Smokers Dependent on Nicotine? A Review of The Evidence. Drug and Alcohol Dependence 59, 83-95.

Guzman, C. R., Pfeiffer, R., Lubin, J., Freedman, N., Cleary, S., Levine, P., \& Caporaso, N. (2016). Determinants of Light and Intermittent Smoking in the U.S.: Results from Three Pooled National Health Surveys. Cancer Epidemiol Biomarkers Prev, 1-26. 
Hackshaw, A., Morris, J. K., Boniface, S., Tang, J.-L., \& Milenkovic, D. (2018). Low cigarette consumption and risk of coronary heart disease and stroke: meta-analysis of 141 cohort studies in 55 study reports. $B M J, 1-14$.

Kementrian Kesehatan Republik Indonesia. (2018). Infodatin: Situasi Umum Konsumsi Tembakau di Indonesia. Jakarta: Pusat Data dan Informasi Kemkes RI.

Kementrian Kesehatan Republik Indonesia. (2019). HTTS 2019: Jangan Biarkan Rokok Merenggut Napas Kita diakses pada 13 Mei 2020 melalui http://sehatnegeriku.kemkes.go.id/baca/rilismedia/20190711/1030815/htts-2019-jangan-biarkan-rokok-merenggut-napas-kita/

Komasari, D., \& Helmi, A. (2000). Faktor-faktor Penyebab Perilaku Merokok Pada Remaja. Jurnal Psikologi Universitas Gadjah Mada Yogyakarta.

Lenk, K., Chen, V., Bernat, D., Forster Jean L., \& Rode, P. (2009). Characterizing and Comparing Young Adult Intermittent and Daily Smokers. Informa Healthcare, 2128-2140.

Lutfiyya, M., Shah, K., Johnson, M., Bales RW, Cha , I., McGrath, C., . . Lipsky, M. (2008). Adolescent Daily Cigarette Smoking: Is Rural Residency a Risk Factor? Rural and Remote Health 8:875.

Martini, S. (2014). Makna Merokok pada Remaja Putri Perokok. Jurnal Psikologi Pendidikan dan Perkembangan, Vol.3, No.2, 119-127.

Republik Indonesia. (2012). Peraturan Pemerintah No. 109 Tahun 2012 tentang Pengamanan Bahan Yang Mengandung Zat Adiktif Berupa Produk Tembakau Bagi Kesehatan. Tambahan Lembaran Negara Republik Indonesia Nomor 5380. Sekertariat Negara. Jakarta.

Rubinstein, M., Rait, M., Sen, S., \& Shiffman, S. (2014). Characteristics of Adolescent Intermittent and Daily Smokers. Addictive Behaviors 39, 1337-1341.

Shiffman, S., Tindle, H., Li, X., Scholl, S., Dunbar, M., \& Miland, C. M. (2012). Characteristics and Smoking Patterns of Intermittent Smokers. Experimental and Clinical Psychopharmacology, Vol.20, No.4, 264277.

Stanton, W., Oei, T., \& Silva, P. (1994). Sociodemographic Characteristics of Adolescent Smokers. International Journal of the Addictions, 29:7, 913-925.

Sutha, W. D. (2018). Knowledge and Smoking Behavior of Junior High School Student. Jurnal Manajemen Kesehatan Yayasan R.S.Dr.Soetomo Vol. 4 No.1, 47-60.

Wang, Y., Sung, H.-Y., Yao, T., Lightwood, J., \& Max, W. (2017). Infrequent and Frequent Nondaily Smokers and Daily Smokers:Their Characteristics and Other Tobacco Use Patterns. Nicotine \& Tobacco Research, 1-8.

World Health Organization. (2015). WHO Report on The Global Tobacco Epidemic, 2014. Switzerland: WHO.

World Health Organization. (2017). WHO Report on the Global Tobacco Epidemic, 2017. Geneva: World Health Organization.

Yusuf, S. (2004). Psikologi Perkembangan Anak dan Remaja. Bandung: PT. Remaja Rosdakarya. 